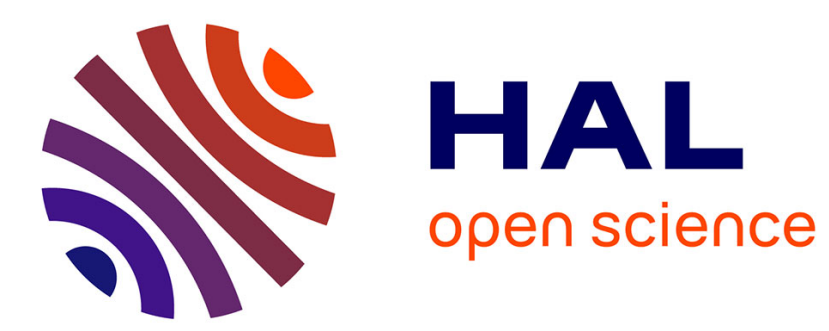

\title{
High temperature sulfidation-oxidation of stainless steels
}

\author{
K. Tjokro, D.J. Young, R. Johansson, B. Ivarsson
}

\section{To cite this version:}

K. Tjokro, D.J. Young, R. Johansson, B. Ivarsson. High temperature sulfidation-oxidation of stainless steels. Journal de Physique IV Proceedings, 1993, 03 (C9), pp.C9-357-C9-364. 10.1051/jp4:1993936 . jpa-00252375

\section{HAL Id: jpa-00252375 https://hal.science/jpa-00252375}

Submitted on 1 Jan 1993

HAL is a multi-disciplinary open access archive for the deposit and dissemination of scientific research documents, whether they are published or not. The documents may come from teaching and research institutions in France or abroad, or from public or private research centers.
L'archive ouverte pluridisciplinaire HAL, est destinée au dépôt et à la diffusion de documents scientifiques de niveau recherche, publiés ou non, émanant des établissements d'enseignement et de recherche français ou étrangers, des laboratoires publics ou privés. 


\title{
High temperature sulfidation-oxidation of stainless steels $\left(^{*}\right)$
}

\author{
K. Tjokro $\left({ }^{1}\right)$, D.J. Young $\left({ }^{1}\right)$, R.E. Johansson $\left({ }^{2}\right)$ and B.G. Ivarsson $\left({ }^{2}\right)$ \\ ( ${ }^{1}$ ) School of Materials Science and Engineering, University of New South Wales, P.O. Box 1, \\ Kensington NSW 2033, Australia \\ $\left({ }^{2}\right)$ Avesta $A B$, S-77480 Avesta, Sweden
}

\begin{abstract}
The alloys 153MA, 253MA and 353MA, Type 310S stainless steel, Type 309S stainless steel and IN601 were all exposed at $900^{\circ} \mathrm{C}$ to a complex gas mixture of $\mathrm{CO} / \mathrm{CO}_{2} / \mathrm{SO}_{2} / \mathrm{N}_{2}$, corresponding to a sulfur partial pressure of $1.3 \times 10^{-3}$ atm and oxygen partial pressure of $3.2 \times 10^{-14} \mathrm{~atm}$. The corrosion kinetics were parabolic in all cases. The rate for IN601 was unacceptably high due to extensive liquid sulfide formation. The other materials all formed solid external scales as well as undergoing some internal corrosion. The rates for all three MA alloys were less than those of the two conventional stainless steels. The corrosion behaviour of all the materials was dominated by sulfide formation as only relatively small amounts of oxides were formed. The same materials were exposed at $800^{\circ} \mathrm{C}$ to a gas mixture corresponding to a sulfur partial pressure of $1.7 \times 10^{-3} \mathrm{~atm}$ and an oxygen partial pressure of $4.9 \times 10^{-16} \mathrm{~atm}$. No liquids were formed, and the corrosion products consisted of an outer scale layer of $(\mathrm{Fe}, \mathrm{Ni})_{1-x} \mathrm{~S}$, and an inner layer containing mixtures of sulfides and oxides. Reaction kinetics were again parabolic. The rates were rather similar, with IN601 reacting fastest, and 353MA slowest.
\end{abstract}

\section{Introduction.}

The presence of sulfur in fossil fuels has been found to lead to high temperature corrosion problems in a number of industries, in which these materials are processed. Examples are superheaters and other heat exchangers, coal gasification systems, gas turbines and carbon baking furnaces $[1,2]$. The resulting atmospheres typically have low oxygen partial pressures and moderate sulfur partial pressures and these often lead to rapid sulfidation. In many cases it has been found that local equilibration between the corrosion product and the gas phase is not achieved [3]. In particular, it has often been found that in gas mixtures in which oxides are stable with respect to sulfides, nonetheless, both oxide and sulfide are simultaneously formed. The thermochemical diagram in figure 1 represents such a situation, where $\mathrm{Cr}_{2} \mathrm{O}_{3}$ should be a stable product, and protection thereby achieved. The failure to form this oxide is a most undesirable result, because mass transfer through the two-phase scale is greatly enhanced and corrosion accelerated.

Stainless steels are commonly used in high temperature applications in order to exploit the economies they offer, together with their generally good oxidation resistance. However, under some industrial process conditions, there is a danger that sulfides of the main alloy constituents will form readily, whereas at the low oxygen partial pressures encountered, the formation of protective $\mathrm{Cr}_{2} \mathrm{O}_{3}$ scales is difficult. Under these conditions, degradation due to sulfidation will be very rapid.

$\left(^{*}\right)$ This paper was also presented at the conference "Application of Stainless Steel '92" in Stockholm. 
SYSTEM ì - S - 0 ot $890 \mathrm{C}$

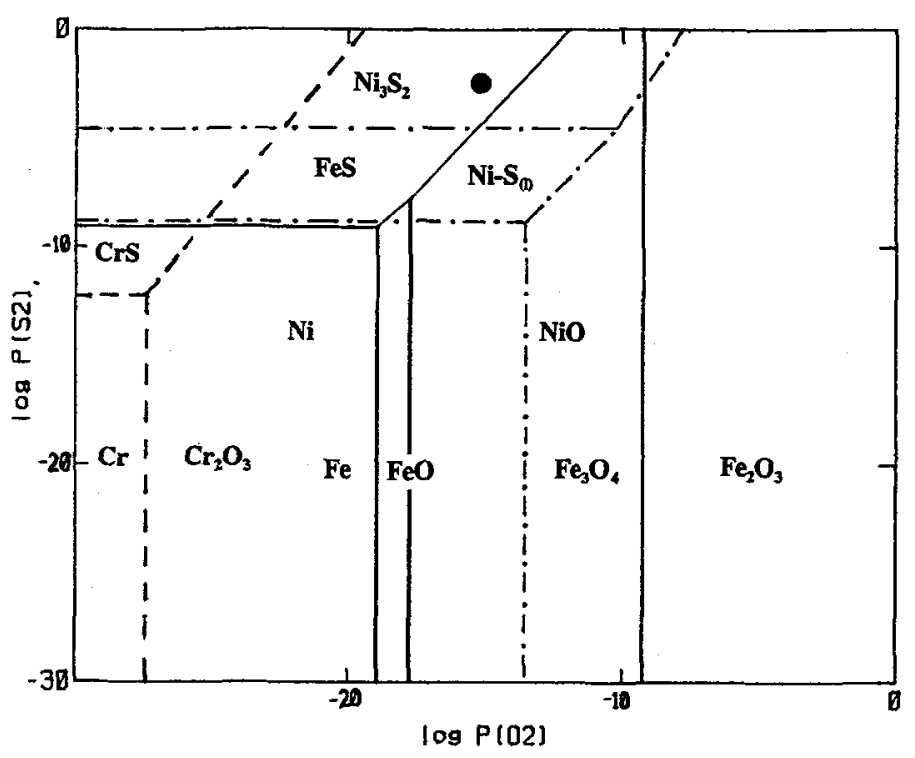

Fig. 1. - Thermochemical diagrams for the systems M-S-O $(\mathrm{M}=\mathrm{Fe}, \mathrm{Ni}, \mathrm{Cr})$ at $800^{\circ} \mathrm{C}$. Experimental conditions represented by filled circle.

Of the commercial alloys used in high temperature application type $310 \mathrm{~S}$ stainless steel has been subjected to extensive laboratory testing in sulfidising/oxidising atmospheres. Rao et al. $[4,5]$ studied the corrosion kinetics at $877^{\circ} \mathrm{C}$. They found that with sulfur partial pressures greater than $2.7 \times 10^{-7} \mathrm{~atm}$ and oxygen pressures of $5.9 \times 10^{-18} \mathrm{~atm}$, the corrosion products were similar to those formed in a purely sulfidising atmosphere. These consisted of a multilayered scale containing $\mathrm{Fe}-\mathrm{Ni}$ rich sulfides in the outer region and an inner layer rich in $\mathrm{Fe}-\mathrm{Cr}-\mathrm{S}$. No $\mathrm{Cr}_{2} \mathrm{O}_{3}$ layer was formed and hence no protection was available.

Natesan [1] also studied the behaviour of type $310 \mathrm{~S}$ at a temperature of $775^{\circ} \mathrm{C}$, a sulfur pressure of $10^{-8}$ atm and an oxygen pressure of less than $10^{-20}$ atm. He also found that the products were dominantly sulfide, even though the thermodynamic equilibrium prediction was that oxide scale formation would be favoured. It was suggested that sulfidation occurred because of the fact that sulfides form much faster than oxide and, eventually, overgrow and bury the oxide.

Working at an oxygen partial pressure of $10^{-13} \mathrm{~atm}$ and sulfur partial pressure of $10^{-5} \mathrm{~atm}$, and a temperature of $900{ }^{\circ} \mathrm{C}$, Nagarajan et al. [6] found that under these more oxidising conditions, the external scale consisted entirely of oxide: an outer iron-rich layer and an inner layer rich in both iron and chromium.

Laboratory work has also been carried out on the sulfidation-oxidation of alloy 800 and other high alloy materials [7-9]. Just like the stainless steels, these materials tend to form sulfides, even under gas conditions where the oxides are expected to be thermodynamically favoured. Oxygen pressures several orders of magnitude greater than those predicted thermodynamically are required in order to stabilise the oxides. An additional problem in the high nickel alloys is the formation of nickel-based sulfides at high sulfur partial pressures. These sulfides are particularly destructive as a liquid phase is readily formed. Even if solid 
nickel sulfides are formed, they grow very rapidly because of their high diffusivities.

The purpose of this paper is to compare the behaviour under sulfidising-oxidising corrosion conditions of a relatively new steel 353MA with the performance of other stainless steels, and Inconel 601. This work continued an evaluation program of the high temperature corrosion resistance of MA steels in which results on carburisation, carburisation-oxidation and nitridation have already been presented [10].

\section{Experimental.}

The alloys tested were 153MA, 253MA, 353MA, Type 310S, Type 309S and IN 601. Nominal compositions for these materials are given in table $I$. Test samples were coupons of dimensions approximately $5 \times 5 \times 1-2 \mathrm{~mm}$ cut from sheet stock. Samples were metallographically ground and polished on all surfaces to a $1 \mu \mathrm{m}$ finish, and ultrasonically cleaned in acetone immediately before use.

Table 1. - Alloy compositions (wt.\%).

\begin{tabular}{|llllllllll|}
\hline AllOY & Fe & \multicolumn{1}{l}{ Ni } & Cr & \multicolumn{1}{l}{ C } & \multicolumn{1}{l}{ Si } & N & Mo & Mn & Other \\
\hline $153 \mathrm{MA}$ & 69.6 & 9.6 & 18.4 & .06 & 1.3 & .15 & .26 & .53 & $.04 \mathrm{Ce}$ \\
$253 \mathrm{MA}$ & 65.5 & 10.9 & 20.8 & .09 & 1.7 & .16 & .24 & .59 & $.04 \mathrm{Ce}$ \\
$353 \mathrm{MA}$ & 36.1 & 34.6 & 25.8 & .05 & 1.5 & .13 & .05 & 1.7 & $.05 \mathrm{Ce}$ \\
$310 \mathrm{~S}$ & 53.8 & 19.1 & 24.7 & .05 & .5 & .07 & .25 & 1.5 & - \\
$309 \mathrm{~S}$ & 62.7 & 12.6 & 22.2 & .06 & .4 & .10 & .37 & 1.5 & - \\
IN601 & 10.4 & 63.9 & 22.9 & .07 & - & - & - & - & $1.4 \mathrm{Al}$ \\
\hline
\end{tabular}

Corrosion reactions were carried out at temperatures of 800 and $900{ }^{\circ} \mathrm{C}$ with samples positioned in the hot zone of a vertical tube furnace, through which controlled gas compositions were flowed. Exposure times were up 25 hours at $800^{\circ} \mathrm{C}$ and up to 3.5 hours at $900^{\circ} \mathrm{C}$. Reaction kinetics were observed using a Mc Bain spring balance, in which the normally cold parts were heated to prevent sulfur contamination. The reaction gas was a mixture of pre-dried $\mathrm{SO}_{2}(0.5 \%), \mathrm{CO}_{2}(8.97 \%), \mathrm{CO}(1.03 \%)$, and $\mathrm{N}_{2}($ bal.), which yielded the equilibrium partial pressures $P\left(\mathrm{O}_{2}\right)=4.9 \times 10^{-16}$ atm and $P\left(\mathrm{~S}_{2}\right)=1.7 \times 10^{-3}$ atm at $800^{\circ} \mathrm{C}$ and $P\left(\mathrm{O}_{2}\right)=3.2 \times 10^{-14}$ atm and $P\left(S_{2}\right)=1.3 \times 10^{-3} \mathrm{~atm}$ at $900^{\circ} \mathrm{C}$. The gas phase equilibria controlling these partial pressures were: $\mathrm{SO}_{2}=1 / 2 \mathrm{~S}_{2}+\mathrm{O}_{2} ; \mathrm{CO}_{2}=\mathrm{CO}+1 / 2 \mathrm{O}_{2}$; $2 \mathrm{CO}=\mathrm{CO}_{2}+\mathrm{C}$ together with other reactions leading to a number of minor species. Equilibrium compositions were calculated using a free energy minimisation computer program named "Chemix" supplied by CSIRO. Gas phase equilibrium was achieved by passing the gas through a supported platinum catalyst bed before it reached the reacting sample.

Reacted samples were characterised by in-situ X-ray diffraction (XRD) and subsequently cross-sectioned for metallography and energy dispersive analysis of X-rays (EDAX). 


\section{Results.}

3.1 KINETICS. - For all alloys at both temperatures, the weight gain was found to increase in a parabolic way with time, as expressed by the rate equation:

$$
\left(\frac{\Delta W}{A}\right)^{2}=k_{\mathrm{p}} t+c
$$

where $\Delta W / A$ is the weight gain per unit surface area formed in time $t, k_{\mathrm{p}}$ is the parabolic rate constant, and $c$ is a constant. The rate constants were evaluated by linear regression of experimental data on this equation. Sample kinetic plots are shown in figure 2 and the rate constants are tabulated in table II. Generally speaking, all the steels tested were more resistant than the nickel-base alloy, IN601. The MA steels performed better than the conventional stainless steels at $900^{\circ} \mathrm{C}$, and were equivalent at $800^{\circ} \mathrm{C}$.

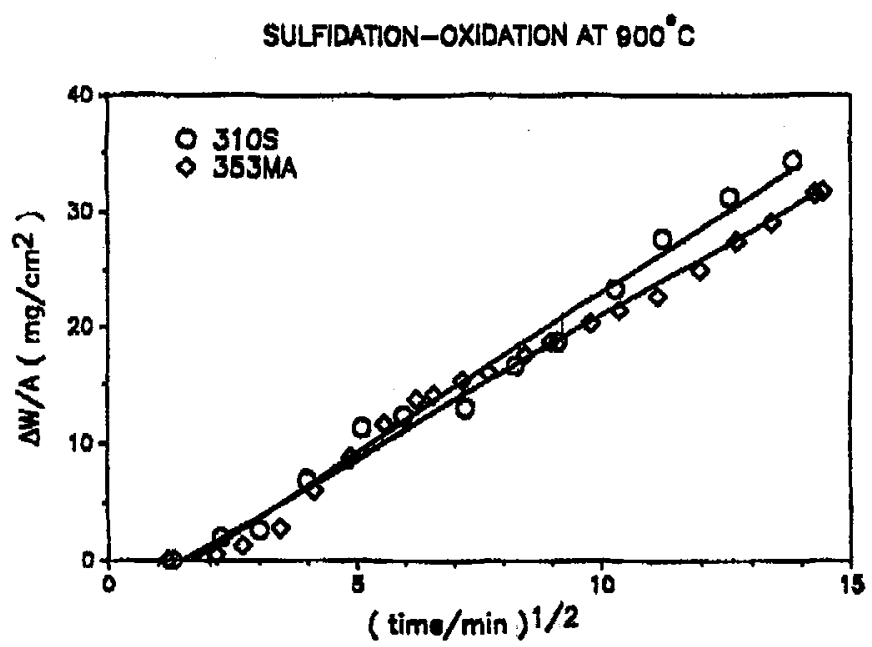

Fig. 2. - Weight gain kinetics at $900^{\circ} \mathrm{C}$ for $310 \mathrm{~S}$ and 353MA.

3.2 MORPHOLOGY AND COMPOSITION OF SCALES. - The steels all developed similar corrosion products which did not alter greatly with temperature. An external scale consisted primarily of an outer layer made up of Fe-Ni rich sulfides, and an inner layer consisting of $\mathrm{Cr}-\mathrm{Fe}$ rich oxide-plus-sulfide mixtures. Examples are shown in figures 3 and 4 . A small quantity of chromium-rich oxide was observed at the inner-outer sublayer interface. The inner scale layers formed on MA steels contained significant silicon levels, reflecting the higher silicon contents of these alloys. Both the outer and inner layers were porous, with the pores in the latter being much finer.

In situ XRD analysis of the scale surfaces yielded the results shown in table III. Analysis by $\mathrm{EDAX}$ confirmed the presence of $(\mathrm{Fe}, \mathrm{Ni})_{9} \mathrm{~S}_{8}$ and $(\mathrm{Fe}, \mathrm{Ni})_{1-x} \mathrm{~S}$ regions at $900{ }^{\circ} \mathrm{C}$, and of 
Table II. - Corrosion Rates $\left(k_{\mathrm{p}} / m g^{2} \mathrm{~cm}^{-4} \mathrm{~min}^{-1}\right)$.

\begin{tabular}{|ccc|}
\hline AlloY & $T=800^{\circ} \mathrm{C}$ & $T=900^{\circ} \mathrm{C}$ \\
\hline $153 \mathrm{MA}$ & 2.6 & $4.5 \pm 0.3$ \\
$253 \mathrm{MA}$ & 2.5 & $3.1 \pm 0.4$ \\
$353 \mathrm{MA}$ & 1.9 & $6.5 \pm 0.5$ \\
$309 \mathrm{~S}$ & 2.9 & $14.7 \pm 1.2$ \\
$310 \mathrm{~S}$ & 2.0 & $9.9 \pm 1.1$ \\
IN601 & 4.4 & $58.5 \pm 2.2$ \\
\hline
\end{tabular}

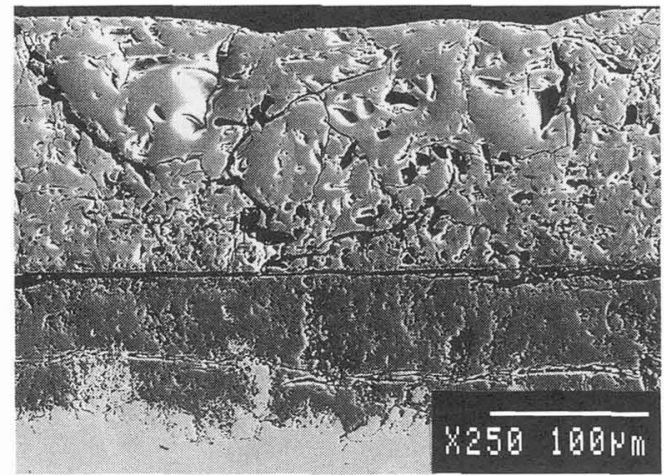

Fig. 3.

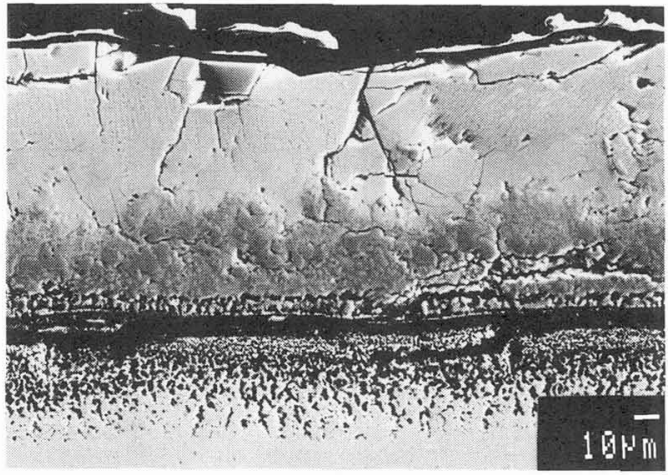

Fig. 4.

Fig. 3. - Cross-section of $310 \mathrm{~S}$ after $3 \mathrm{~h}$ corrosion at $900{ }^{\circ} \mathrm{C}$.

Fig. 4. - Cross-section of $353 \mathrm{MA}$ after $3.5 \mathrm{~h}$ corrosion at $900^{\circ} \mathrm{C}$.

$(\mathrm{Fe}, \mathrm{Ni})_{1-x} \mathrm{~S}$ at $800^{\circ} \mathrm{C}$. The chromium sulfides were too finely dispersed for chemical analysis. The sulfur content of the inner layers was much lower, because of the presence there of chromium-rich oxide, as shown in table IV. The sulfur content of the inner layer increased from the scale-alloy interface towards the outer layer, whereas the chromium content decreased from a maximum value adjacent to the alloy.

Some degree of internal corrosion was always observed, but was significant only for 353MA and Type 310S. Although the precipitates were too fine for individual analysis, they were found to be enriched in chromium and silicon. Only low levels of sulfur were present in the internal precipitation region.

The only nickel-base alloy tested, IN601, behaved very differently at the two temperatures. At $800^{\circ} \mathrm{C}$ it corroded to produce a scale quite like those grown on the steels. The outer scale layer was the monosulfide $(\mathrm{Ni}, \mathrm{Fe})_{1-x} \mathrm{~S}$, but was much richer in nickel than the corresponding layers formed on steels. The inner layer appeared to be made up to two sub-layers, the innermost being essentially $\mathrm{Cr}_{2} \mathrm{O}_{3}$ with a small amount of sulfide, and the other being close to $\mathrm{CrS}$ in composition. Both sublayers contained significant levels of aluminium, but the 
Table III. - Phases in scales detected by XRD analysis of surface $\left({ }^{*}\right)$.

\begin{tabular}{|ccc|}
\hline AllOY & $T=800^{\circ} \mathrm{C}$ & $T=900^{\circ} \mathrm{C}$ \\
\hline $153 \mathrm{MA}$ & $M, C r_{5} S_{6}$ & $P, M, C r_{5} S_{6}, C r_{3} S_{4}$ \\
$253 \mathrm{MA}$ & $M$ & $P, M, C r_{2} S_{3}$ \\
$353 \mathrm{MA}$ & $M$ & $P$ \\
$310 \mathrm{~S}$ & $M, C r_{2} S_{3}$ & $P, M, C r_{7} S_{8}, C r_{2} S_{3}$ \\
$309 S$ & $M, C r_{5} S_{6}$ & $P, M, C r_{3} S_{4}$ \\
$I N 601$ & $M, C r_{2} S_{3}$ & $N 3, M$ \\
\hline
\end{tabular}

$\left(^{*}\right) M=(\mathrm{Fe}, \mathrm{Ni})_{1-x} \mathrm{~S}, P=(\mathrm{Fe}, \mathrm{Ni})_{9} \mathrm{~S}_{8}, \mathrm{~N} 3=\mathrm{Ni}_{3} \mathrm{~S}_{2}$

Table IV. - Scale inner layer compositions (average wt.\%).

\begin{tabular}{|c|c|c|c|c|c|c|c|c|c|c|}
\hline \multirow[t]{2}{*}{ Alloy } & \multicolumn{3}{|r|}{$\mathbf{T}$} & $=$ & \multirow{2}{*}{$\frac{800^{\circ} \mathrm{C}}{\mathrm{si}}$} & \multicolumn{2}{|r|}{$\mathbf{T}$} & $=$ & \multicolumn{2}{|c|}{$900^{\circ} \mathrm{C}$} \\
\hline & Cr & $\mathrm{Fe}$ & $\mathrm{Ni}$ & s & & $\mathrm{Cr}$ & $\mathrm{Fe}$ & $\mathrm{Ni}$ & s & si \\
\hline $153 \mathrm{MA}$ & 40 & 22 & 2 & 8 & 2.8 & 33 & 25 & 1 & 11 & 2.7 \\
\hline $253 \mathrm{MA}$ & 40 & 19 & 6 & 12 & 4.4 & 20 & 9 & 1 & 20 & 4.9 \\
\hline $353 \mathrm{MA}$ & 42 & 20 & 1.5 & 12 & 3.8 & 67 & 2 & 3 & 2 & 5.0 \\
\hline $310 s$ & 44 & 12 & 0.5 & 10 & 1.0 & 43 & 20 & 1 & 5 & 0.9 \\
\hline $309 \mathrm{~S}$ & 40 & 22 & 0.5 & 9 & 0.8 & 36 & 25 & 1 & 9 & 0.8 \\
\hline $\begin{array}{r}\text { IN601* (a) } \\
\text { (b) }\end{array}$ & $\begin{array}{l}49 \\
48\end{array}$ & $\begin{array}{l}4 \\
3\end{array}$ & $\frac{1.5}{5}$ & $\begin{array}{r}9 \\
28\end{array}$ & $\begin{array}{l}3.7(\mathrm{Al}) \\
4.3(\mathrm{Al})\end{array}$ & & & & & \\
\hline
\end{tabular}

$\left({ }^{*}\right)(a)$ innermost; (b) intermediate.

phase containing this element was not identified.

At $900^{\circ} \mathrm{C}$, the reaction products on IN601 were entirely different (Fig. 5). An outer layer of irregular thickness was made of at least four phases. These were identified by XRD and EDAX as $\mathrm{Ni}_{3} \mathrm{~S}_{2},\left(\mathrm{Fe}, \mathrm{Ni}_{9} \mathrm{~S}_{8}, \mathrm{FeCr}_{2} \mathrm{~S}_{4}\right.$ and metal of approximate composition Ni-20 wt.\% $\mathrm{Fe}$. Beneath this complex layer was a thin layer of $\mathrm{Al}_{2} \mathrm{O}_{3}$ plus mixed sulfides, and a thicker, innermost two-phase layer of approximate composition $\mathrm{FeCr}_{2} \mathrm{~S}_{4}$ plus $\mathrm{Ni}_{3} \mathrm{~S}_{2}$.

\section{Discussion/Conclusions.}

All alloys formed sulfides of iron and nickel, in accord with thermodynamic prediction. However, they also formed both sulfides and oxides of chromium, despite the fact that $\mathrm{Cr}_{2} \mathrm{O}_{3}$ is predicted to be stable with respect to the chromium sulfides (Fig. 1). The rather high corrosion rates are thus a consequence of failure to form continuous $\mathrm{Cr}_{2} \mathrm{O}_{3}$ scale layers. 


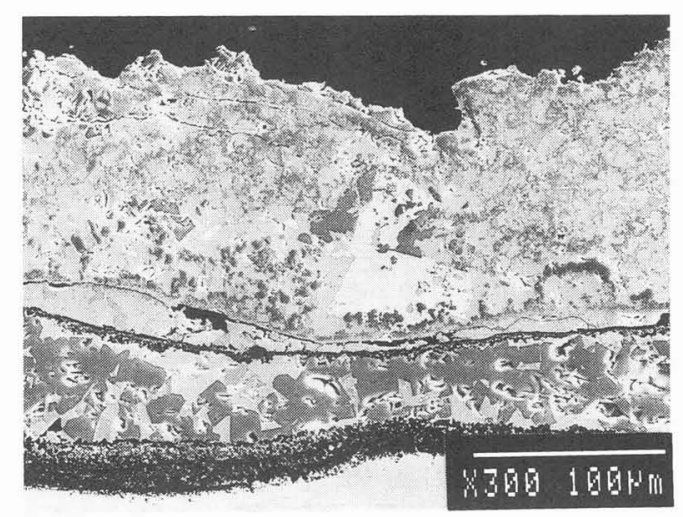

Fig. 5. - Cross-section of IN601 after 80 min corrosion at $900^{\circ} \mathrm{C}$.

Alloy IN601 differs greatly from the stainless steels in its corrosion behaviour at $900^{\circ} \mathrm{C}$, but is rather similar at $800^{\circ} \mathrm{C}$. This is due to the formation of a liquid nickel-rich sulfide at the higher temperature, as shown by the presence of $\mathrm{Ni}_{3} \mathrm{~S}_{2}$ in the product scale. This phase is not in fact stable at $900^{\circ} \mathrm{C}$, and its presence in the corrosion product shows that liquid sulfide was formed at the reaction temperature. When this liquid was cooled, it decomposed to form $\mathrm{Ni}_{3} \mathrm{~S}_{2},(\mathrm{Fe}, \mathrm{Ni})_{9} \mathrm{~S}_{8}$ and a metal phase. Even though protective phases like $\mathrm{Al}_{2} \mathrm{O}_{3}$ and $\mathrm{FeCr}_{2} \mathrm{~S}_{4}$ were present, they provided very little protection because of the overwhelming effect of the liquid phase.

The stainless steels, and IN601 at $800^{\circ} \mathrm{C}$, all formed similar scales, containing thick outer layers of sulfide rich in iron and nickel. The higher nickel content of the $(\mathrm{Fe}, \mathrm{Ni})_{1-x} \mathrm{~S}$ phase formed on IN601 contributed to the higher corrosion rate through the increased defect level of this phase which results from its non-ideal solution behaviour [11]. The stainless steels all corroded at $800^{\circ} \mathrm{C}$ with essentially the same rate because they formed scales of closely similar compositions and phase contributions.

At $900{ }^{\circ} \mathrm{C}$, a significant range of corrosion rates was observed. In general, the MA steels reacted two to three times slower than the conventional grades of $309 \mathrm{~S}$ and $310 \mathrm{~S}$. The slower growing scales on MA steels had substantially thinner inner layers, which contained much more silicon than the scales on $309 \mathrm{~S}$ or $310 \mathrm{~S}$. It is evident from the compositional analyses that the inner layer on $353 \mathrm{MA}$ is almost entirely $\mathrm{Cr}_{2} \mathrm{O}_{3}$ and $\mathrm{SiO}_{2}$, whereas on $310 \mathrm{~S}$ and $309 \mathrm{~S}$, the inner layers are also mainly oxide, but have high iron contents. The higher diffusivities of iron oxides constitute the reason for the lower degree of protection afforded by these scale layers.

The 153MA and 253MA scale inner layers have quite high sulfide levels, and yet grow slower than the oxide layers on $309 \mathrm{~S}$ and $310 \mathrm{~S}$. the absence of rapid diffusion in the presence of the sulfides is atrributed to the dispersed polyphase nature of these layers: the lack of a continuous sulfide phase means that its contribution to mass transport is small.

The ability of the MA steels to form moderately protective inner scale layers is due to their relatively high combined chromium and silicon levels. It also reflects the fact that the protective oxides readily nucleated on these steels in sulfidising-oxidising atmospheres. This ability is obviously related to the presence of significant silicon levels, but may also be due in part to the presence of the reactive element cerium. These effects are important at $900{ }^{\circ} \mathrm{C}$, but not at $800^{\circ} \mathrm{C}$ where all alloys grew inner layers containing substantial levels of iron. An 
examination of diffusional depletion of chromium from the substrate alloy would be of use in analysing this result.

\section{References}

[1] NATESAN K., High Temperature Corrosion, R.A. Rapp Ed. (NACE, Houston, 1982) p.336.

[2] STRINGER J., High Temperature Oxidation and Sulphidation Processes, J.D. Embury Ed. (Pergamon, New York, 1990) p. 257.

[3] Gesmundo F., Young D.J., Roy S.K., High Temp. Mater. Proc. 8 (1989) 149.

[4] RaO D.B., JaCOB K.T., NelSON H.G., Metall. Trans. A 14A (1983) 295.

[5] RaO D.B., Nelson H.G., Oxid. Met. 12 (1978) 111.

[6] Nagarajan V., SMith R.D., Wright I.G., Oxid. Met. 31 (1989) 123.

[7] Williams D.S., Moller R., Grabke H.J., Oxid. Met. 16 (1981) 253.

[8] Perkins R.A., Proc. Petten Int. Conf. Alloy 800 (North Holland Publishing, 1978) p. 213.

[9] Hussey R.J., Papaiacovou P., GRabke H.J., Werkst. Korros. 37 (1986) 578.

[10] TJokro K., Young D.J., JohansSon R., Redmond J.D., Proc. Corrosion 91, paper 548 (NACE, Houston 1991).

[11] ORCHARD J.P., YOUNG D.J., J. Electrochem. Soc. 136 (1989) 545. 